\title{
Characterization of Tomato yellow spot virus, a novel tomato-infecting begomovirus in Brazil
}

\author{
Renata Faier Calegario(1), Sávio de Siqueira Ferreira(1), Eduardo Chumbinho de Andrade(1) \\ and Francisco Murilo Zerbini ${ }^{(1)}$
}

\begin{abstract}
(1)Universidade Federal de Viçosa, Dep. de Fitopatologia, Av. P.H. Rolfs, s/no, CEP 36570-000 Viçosa, MG, Brazil. E-mail: rfcalega@carpa.ciagri.usp.br, saviobqi2002@yahoo.com.br, eandrade@cnpmf.embrapa.br, zerbini@ufv.br
\end{abstract}

\begin{abstract}
The objective of this work was the biological and molecular characterization of a begomovirus detected in São Joaquim de Bicas, Minas Gerais, Brazil, named TGV-[Bi2], by determining its host range, complete nucleotide sequence and phylogenetic relationships with other begomoviruses. Biological characterization consisted of a host range study using either sap inoculation or particle bombardment as inoculation methods. The yellow spot virus can infect plants in Solanaceae and Amaranthaceae, including economically importat crops as sweet pepper, and weeds as Datura stramonium and Nicotiana silvestris. For the molecular characterization, the fulllength genome (DNA-A and DNA-B) was amplified, cloned and completely sequenced. Sequence comparisons and phylogenetic analyses indicated that TGV-[Bi2] constitutes a novel begomovirus species named Tomato yellow spot virus (ToYSV), closely related to Sida mottle virus (SiMoV).
\end{abstract}

Index terms: Lycopersicon esculentum, Bemisia tabaci, ToYSV, molecular biology, geminivirus, whitefly.

\section{Caracterização do Tomato yellow spot virus, um novo begomovírus isolado de tomateiro no Brasil}

\begin{abstract}
Resumo - O objetivo deste trabalho foi a caracterização biológica e molecular de um begomovírus detectado em tomateiros em São Joaquim de Bicas, Minas Gerais, denominado TGV-[Bi2]. A caracterização biológica consistiu em teste de gama de hospedeiros, realizado por meio de inoculação via extrato foliar tamponado ou bombardeamento de partículas. O isolado TGV-[Bi2] infecta plantas das famílias Solanaceae e Amaranthaceae, inclusive espécies economicamente importantes como o pimentão, e algumas plantas daninhas como Datura stramonium e Nicotiana silvestris. A caracterização molecular consistiu na clonagem e seqüenciamento de seu genoma completo (DNA-A e DNA-B). A comparação de sequiências e análise filogenética indicaram que o TGV-[Bi2] constitui uma nova espécie de begomovírus, denominada Tomato yellow spot virus (ToYSV), filogeneticamente relacionado ao Sida mottle virus (SiMoV).
\end{abstract}

Termos para indexação: Lycopersicon esculentum, Bemisia tabaci, ToYSV, biologia molecular, geminivírus, mosca-branca.

\section{Introduction}

The Geminiviridae family is comprised of plant viruses with a circular single-stranded DNA genome, and a particle morphology of twinned incomplete icosahedra (Rojas et al., 2005). The family is divided into four genera (Mastrevirus, Curtovirus, Topocovirus and Begomovirus) according to the type of insect vector, host range, genomic organization and phylogeny (Stanley et al., 2005). Viruses classified into the genus Begomovirus are transmitted by the whitefly Bemisia tabaci (Homoptera: Aleyrodidae), infect dicotyledoneous plants, and have mono- or (mostly) bipartite genomes. Begomoviruses are considered to be an emergent group of plant viruses, due to the high incidence and severity of diseases caused by them over the last three decades, in tropical and subtropical regions of the world (Polston \& Anderson, 1997; Legg \& Thresh, 2000; Morales \& Anderson, 2001; Briddon, 2003).

Novel begomovirus species infecting tomato (Lycopersicon esculentum Mill.) were detected in the 1990's in different regions of Brazil, after the introduction and quick dissemination of B biotype of $B$. tabaci (Ribeiro et al., 2003). In the Triângulo Mineiro region of Minas Gerais State, a novel bipartite begomovirus was detected in tomato plants growing under greenhouse conditions (Fernandes et al., 2006). The comparison of the complete nucleotide sequences of the DNA-A and DNA-B 
components with other begomoviruses indicated that this was a distinct species, named Tomato rugose mosaic virus (ToRMV). A second begomovirus, named Tomato chlorotic mottle virus (ToCMoV) was isolated from tomato plants in Zona Metalúrgica, a region of Minas Gerais State, and characterized molecularly and biologically (Ambrozevicius et al., 2002; Ribeiro et al., 2003). The sequence identity between ToCMoV and ToRMV is $86 \%$ for the DNA-A and 60\% for DNA-B, which demonstrates they are distinct, although closely related viruses. Three begomovirus species infecting the common weed Sida have also been sequenced (Sida mottle virus, SiMoV; Sida yellow mosaic virus, SiYMV; and Sida micrantha mosaic virus, SimMV) (Jovel et al., 2004).

A third begomovirus isolate, provisionally named TGV[Bi2] (Tomato geminivirus-[Bi2]), was obtained from a tomato plant collected near São Joaquim de Bicas, in Minas Gerais State, causing symptoms which were much more severe than those caused by ToRMV and ToCMoV (Ambrozevicius et al., 2002). Tomato plants infected by TGV-[Bi2] show intense yellow mosaic, leaf roll, reduction of leaf area and generalized dwarfing. Determining its host range may assist in the identification of alternate hosts and virus reservoirs, which could serve as inoculum sources for field outbreaks, and may indicate additional crop plants that could be infected by the virus.

The objective of the present work was to carry out the biological and molecular characterization of TGV-[Bi2], by determining its host range, complete nucleotide sequence and phylogenetic relationships with other begomoviruses.

\section{Material and Methods}

The TGV-[Bi2] isolate was obtained from a tomato plant showing yellow mosaic, leaf distortion and dwarfing, collected near São Joaquim de Bicas, at Zona Metalúrgica of Minas Gerais State (Ambrozevicius et al., 2002). The replicative form (RF) of the viral genome was extracted from the collected plant (Gilbertson et al., 1991), treated with RNase A to eliminate possible viruses occurring in mixed infections, and used for the biolistic inoculation (Aragão et al., 1996) of Nicotiana benthamiana plants. DNA of all inoculated plants was extracted (Dellaporta et al., 1983) and used as a template for PCR-amplification of DNA-A fragments using the universal begomovirus oligonucleotides PAL1v1978 and PAR1c496 (Rojas et al., 1993). The results were analyzed by agarose gel electrophoresis to check for the presence of amplicons with 1,100 to 1,400 nucleotides (nt); amplicons were partially sequenced from 15 independent PCR reactions, which yielded identical sequences and confirmed the presence of a single begomovirus. The isolate was maintained in $N$. benthamiana and $N$. glutinosa plants by successive sap inoculations using $0.1 \mathrm{M}$ sodium phosphate $\mathrm{pH} 8$ with $0.1 \%$ sodium sulfite. All plants were maintained in a greenhouse at the Plant Pathology Department, Universidade Federal de Viçosa, Viçosa, MG.

The biological characterization consisted on a host range study using species from Amaranthaceae, Chenopodiaceae, Cucurbitaceae, Fabaceae and Solanaceae: Capsicum annuum 'Ikeda', Chenopodium quinoa, Cucurbita pepo 'Caserta', Datura stramonium, Gomphrena globosa, Lycopersicon esculentum 'Miller Early Pack', 'Rutgers' and 'Santa Clara', Nicotiana benthamiana, Nicotiana clevelandi, Nicotiana glutinosa, Nicotiana rustica, Nicotiana silvestris, Nicotiana tabacum 'Havana 425', 'Samsun', 'TNN', and 'Xanthi', Phaseolus vulgaris 'Ouro Negro' and 'Pérola' and Solanum melongena.

Plants were sap-inoculated or biolistically-inoculated. Viral DNA used for biolistics was extracted by grinding $2 \mathrm{~g}$ of infected leaves in liquid nitrogen. The ground tissue was transferred to $1.5 \mathrm{~mL}$ microfuge tubes containing $500 \mu \mathrm{L}$ lysis buffer $(50 \mathrm{mM}$ Tris- $\mathrm{HCl} \mathrm{pH} 7.5,100 \mathrm{mM}$ $\mathrm{NaCl}, 50 \mathrm{mM}$ EDTA, $10 \mathrm{mM}$ 2-mercaptoethanol, $0.5 \% \mathrm{SDS}$ ). The tube was vortexed for $2 \mathrm{~min}$ and incubated at room temperature for $15 \mathrm{~min}$. Subsequently, $150 \mu \mathrm{L}$ phenol were added to each tube, followed by 2 min vortexing and 2 min incubation at room temperature, followed by the addition of $150 \mu \mathrm{L}$ chloroform, 2 min vortexing and centrifugation at $10,000 \mathrm{~g}$ for $2 \mathrm{~min}$. Supernatant was transferred to a new tube, and one volume of isopropanol was added, followed by incubation at $-20^{\circ} \mathrm{C}$ for 12 hours. The solution was then centrifuged at $10,000 \mathrm{~g}$ for $5 \mathrm{~min}$. The supernatant was discarded, the pellet was washed with $500 \mu \mathrm{L}$ of $70 \%$ ethanol and resuspended in $200 \mu \mathrm{L}$ of TE with RNase A. Then, one volume of phenol: chloroform was added and the solution was agitated for $1 \mathrm{~min}$ and centrifuged at $10,000 \mathrm{~g}$ for $2 \mathrm{~min}$. The supernatant was collected, and $500 \mu \mathrm{L}$ of $100 \%$ ethanol were added, followed by incubation for $10 \mathrm{~min}$ at $-20^{\circ} \mathrm{C}$. A new centrifugation was done at $10,000 \mathrm{~g}$ for $5 \mathrm{~min}$, and the supernatant was discarded. The pellet was washed with $500 \mu \mathrm{L}$ of $70 \%$ ethanol and resuspended in $30 \mu \mathrm{L}$ of TE with Rnase A.

Plants inoculated with the virus were maintained in the greenhouse and observed for the appearance of symptoms until 35 days after inoculation. Infection was confirmed by 
PCR using universal begomovirus primers as described above. The experiment was repeated three times.

Molecular characterization of TGV-[Bi2] consisted on the determination and analysis of its complete DNA sequence. Viral DNA was extracted (Dellaporta et al., 1983), and the RF was amplified using the Templiphi kit according to manufacturer's instructions. DNA concentration was visually estimated in ethidium bromidestained agarose gels using mass standards. Approximately $500 \mathrm{ng}$ of viral DNA were cleaved with each of the following restriction endonucleases: Apa I, BamH I, Cla I, Hind III, Not I, Sac I, Sma I, Xba I and Xho I. An aliquot of cleaved DNA was submitted to electrophoresis in order to identify the enzyme that cleaved each DNA component in a single site, thus allowing ligation to a plasmid vector. Cloning was carried out according to standard procedures (Sambrook \& Russel, 2001), with the exception that ligation reactions were prepared with a 1:12 vector:insert ratio. Clones corresponding to both DNA components were sequenced in both orientations using the BigDye Terminator Cycle Sequencing Ready Reaction kit and an ABI 310, using internal primers designed after each sequencing step.

Nucleotide and deduced amino acid sequences were compared to those of other begomoviruses deposited in the GenBank (Table 1) using DNAMan version 4.0. Nucleotide identities were calculated using the following parameters: K-tuple $=2$, Gap open $=10$, Gap penalty $=7$, and Gap extension =5. Amino acid identities were calculated using the BLOSUM matrix with the following parameters: K-tuple $=2$, Gap open $=10$, Gap penalty $=4$, and Gap extension $=0.1$. Phylogenetic trees based on the complete nucleotide sequences of DNA-A and DNA-B were prepared using MEGA 3.1 (Kumar et al., 2004) from multiple alignments obtained with Clustal W (Thompson et al., 1994). Trees were constructed with the UPGMA method, and branches were bootstraped with 1,000 replications.

Table 1. Begomovirus sequences used for pairwise sequence comparisons and phylogenetic analysis.

\begin{tabular}{|c|c|}
\hline Viral species & GenBank access number \\
\hline Abutilon mosaic virus (AbMV) & NC_001928 (DNA-A) and NC_001929 (DNA-B) \\
\hline African cassava mosaic virus (ACMV) & NC_001467 (DNA-A) and NC_001468 (DNA-B) \\
\hline Bean dwarf mosaic virus (BDMV) & NC_001931 (DNA-A) and NC_001930 (DNA-B) \\
\hline Bean golden mosaic virus $(\mathrm{BGMV})^{(1)}$ & NC_004042 (DNA-A) and NC_004043 (DNA-B) \\
\hline Bean golden yellow mosaic virus (BGYMV) & NC_001439 (DNA-A) and NC_001438 (DNA-B) \\
\hline Chino del tomate virus (CdTV) & NC_003830 (DNA-A) and NC_003831 (DNA-B) \\
\hline Macroptilium mosaic Puerto Rico virus (MMPRV) & NC_004097 (DNA-A) and NC_004098 (DNA-B) \\
\hline Pepper golden mosaic virus (PGMV) & NC_004101 (DNA-A) and NC_004096 (DNA-B) \\
\hline Pepper huasteco yellow vein virus (PHYVV) & NC_001359 (DNA-A) and NC_001369 (DNA-B) \\
\hline Potato yellow mosaic virus (PYMV) & NC_001934 (DNA-A) and NC_001935 (DNA-B) \\
\hline Potato yellow mosaic Trinidad virus (PYMTV) & NC_004638 (DNA-A) and NC_004644 (DNA-B) \\
\hline Sida golden mosaic virus (SGMV) & NC_002046 (DNA-A) and NC_002047 (DNA-B) \\
\hline Sida golden mosaic Costa Rica virus (SGMCRV) & NC_004657 (DNA-A) and NC_004658 (DNA-B) \\
\hline Sida golden mosaic Honduras virus (SGMHoV) & NC_004659 (DNA-A) and NC_004660 (DNA-B) \\
\hline Sida micrantha mosaic virus (SimMV-[A2B2] $)^{(1)}$ & NC_005330 (DNA-A) and NC_005331 (DNA-B) \\
\hline Sida mottle virus (SiMoV-[A1B3] $)^{(1)}$ & $\mathrm{AJ} 557450$ (DNA-A) and AJ557̄454 (DNA-B) \\
\hline Sida yellow mosaic virus (SiYMV) ${ }^{(1)}$ & NC 004639 (DNA-A) \\
\hline Sida yellow vein virus (SYVV) & NC_004661 (DNA-A) and NC_004662 (DNA-B) \\
\hline Squash leaf curl virus (SqLCV) & NC_001936 (DNA-A) and NC_001937 (DNA-B) \\
\hline Tomato golden mosaic virus (TGMV) ${ }^{(1)}$ & NC_001507 (DNA-A) and NC_001508 (DNA-B) \\
\hline Tomato leaf curl New Delhi virus (TLCNDV) & $\mathrm{NC}^{-} 004611$ (DNA-A) and NC_004612 (DNA-B) \\
\hline Tomato chlorotic mottle virus $(\mathrm{ToCMV}-[\mathrm{Se} 1])^{(1)}$ & $\mathrm{NC}^{-} 003664$ (DNA-A) and $\mathrm{NC}^{-} 003665$ (DNA-B) \\
\hline Tomato chlorotic mottle virus $(\mathrm{ToCMV}-[\mathrm{Bt1}])^{(1)}$ & AY090557 (DNA-A) \\
\hline Tomato chlorotic mottle virus $(\text { ToCMV }-[\operatorname{Ig} 1])^{(1)}$ & DQ336353 (DNA-A) and DQ336354 (DNA-B) \\
\hline Tomato mottle virus (ToMoV) & NC_001938 (DNA-A) and NC_001939 (DNA-B) \\
\hline Tomato rugose mosaic virus (ToRMV) ${ }^{(1)}$ & NC_002555 (DNA-A) and NC_002556 (DNA-B) \\
\hline Tomato severe rugose virus $(\mathrm{ToSRV}-[\mathrm{Ub} 2])^{(1)}$ & AY029750 (DNA-A) \\
\hline Tomato yellow leaf curl virus (TYLCV) & NC_004005 (monopartite) \\
\hline Tomato yellow spot virus $(\text { ToYSV-[Bi2] })^{(1)}$ & DQ336350 (DNA-A) and DQ336351 (DNA-B) \\
\hline Watermelon chlorotic stunt virus (WCSV) & NC_003708 (DNA-A) and NC_003709 (DNA-B) \\
\hline
\end{tabular}

${ }^{(1)}$ Viruses obtained from samples collected in Brazil. 


\section{Results and Discussion}

The TGV-[Bi2] isolate was capable of systemically infecting plants of Amaranthaceae (G. globosa) and Solanaceae, including $C$. annuиm 'Ikeda', D. stramonium, L. esculentum 'Miller Early Pack', 'Rutgers' and 'Santa Clara', N. benthamiana, N. clevelandi, N. glutinosa, $N$. rustica, $N$. tabacum and $N$. silvestris (Table 2). In general, symptoms induced by TGV-[Bi2] in all hosts were severe, and consisted of yellow or golden mosaic, blisters, crinkled leaves, and dwarfing (Figure $1 \mathrm{~A}, \mathrm{~B}$ and $\mathrm{C}$ ). These severe symptoms were similar to those previously observed for this viral isolate (Ambrozevicius et al., 2002). N. silvestris and N. tabacum 'Havana' plants displayed a latent infection when sap-inoculated. G. globosa displayed a latent infection when biolistically inoculated. Infection was confirmed by PCR-amplification of a DNA-A-specific fragment (Figure $1 \mathrm{D}$ ).

As observed for other begomoviruses (Urbino et al., 2004; Rajeshwari et al., 2005; Rothenstein et al., 2005; Ariyo et al., 2006), a number of differences were observed between the two inoculation methods in terms of the establishment of a systemic infection. Sap inoculation was an efficient mode of transmission. All plants of $N$. benthamiana, $N$. glutinosa, $N$. rustica and N. tabacum 'Xhanti' were infected by sap inoculation. Interestingly, the virus could not be saptransmitted to tomato. Latent infection was confirmed by PCR in N. silvestris and N. tabacum 'Havana', albeit at a low efficiency (only $26 \%$ of the inoculated plants were infected). The possibility of symptoms appearing later in the infection, beyond the period of evaluation used in this work, cannot be ruled out.

Efficient sap transmission has not been observed for tomato-infecting begomoviruses from Brazil such as ToRMV and ToCMoV-[Ig1] (Ambrozevicius et al., 2002; Fernandes et al., 2006), although it has been reported for ToCMoV-[Se1] (Ribeiro et al., 2007). Clearly, this property varies for each distinct begomovirus species. It is possible that TGV-[Bi2] is capable of invading the mesophyll and the epidermis of Nicotiana species, which could explain its sap-transmission to these hosts. Analysis of tissue tropism using immunolocalization or in situ hybridization could confirm this hypothesis.

Table 2. Plant species inoculated with Tomato yellow spot virus-[Bi2] (ToYSV-[Bi2]) in the host range experiments, and symptoms observed for each inoculation method.

\begin{tabular}{|c|c|c|c|c|}
\hline \multirow[t]{3}{*}{ Species/cultivar } & \multicolumn{4}{|c|}{ Inoculation method } \\
\hline & \multicolumn{2}{|c|}{ Plant sap } & \multicolumn{2}{|c|}{ Biolistics } \\
\hline & $\begin{array}{c}\text { Infected/ } \\
\text { inoculated }^{(1)}\end{array}$ & Symptoms $^{(2)}$ & $\begin{array}{c}\text { Infected/ } \\
\text { inoculated }\end{array}$ & Symptoms \\
\hline Capsicum annuum & $4 / 15$ & ym, ld & $12 / 15$ & $\mathrm{ym}, \mathrm{ld}, \mathrm{df}$ \\
\hline Chenopodium quinoa & $0 / 15$ & - & $0 / 15$ & - \\
\hline Cucurbita pepo 'Caserta' & $0 / 15$ & - & n.i. ${ }^{(3)}$ & n.i. \\
\hline Datura stramonium & $13 / 15$ & $y m, l d, d f$ & $0 / 15$ & - \\
\hline Gomphrena globosa & $0 / 15$ & - & $3 / 15$ & - \\
\hline Lycopersicon esculentum 'Miller Early Pack' & $0 / 45$ & - & $34 / 45$ & ym, ld \\
\hline L. esculentum 'Rutgers' & $0 / 24$ & - & $17 / 24$ & $y m$, ld \\
\hline L. esculentum 'Santa Clara' & $0 / 24$ & - & $16 / 24$ & $y m$, ld \\
\hline Nicotiana benthamiana & $24 / 24$ & $\mathrm{ym}, \mathrm{ld}, \mathrm{df}$ & $36 / 45$ & $y m, 1 d$ \\
\hline N. clevelandi & $12 / 15$ & $y m, ~ l d, d f$ & $0 / 15$ & - \\
\hline N. glutinosa & $15 / 15$ & $\mathrm{ym}, \mathrm{ld}, \mathrm{df}$ & $12 / 24$ & $\mathrm{ym}, \mathrm{ld}, \mathrm{df}$ \\
\hline N. rustica & $15 / 15$ & $y m, ~ l d, d f$ & $0 / 15$ & - \\
\hline N. sylvestris & $2 / 15$ & - & $0 / 15$ & - \\
\hline N. tabacum 'Havana' & $6 / 15$ & - & $0 / 15$ & - \\
\hline N. tabacum 'Samsun' & $3 / 15$ & $y m$, ld & $3 / 15$ & $y m$, ld \\
\hline N. tabacum 'TNN' & $2 / 15$ & $\mathrm{ym}, \mathrm{dd}, \mathrm{b}$ & $3 / 15$ & ym, ld, b \\
\hline N. tabacum 'Xanthi' & $15 / 15$ & ym & $8 / 15$ & $\mathrm{ym}$ \\
\hline Phaseolus vulgaris 'Ouro Negro' & $0 / 15$ & - & $0 / 15$ & - \\
\hline P. vulgaris 'Pérola' & $0 / 15$ & - & $0 / 15$ & - \\
\hline Solanum melongena & $0 / 15$ & - & $0 / 15$ & - \\
\hline
\end{tabular}

${ }^{(1)}$ Total number of plants inoculated with ToYSV-[Bi2] in three independent experiments. ${ }^{(2)}$ Symptoms in systemic (noninoculated) leaves are represented by: b, blisters; df, dwarfing; ld, leaf distortion; ym, yellow mosaic; -, no symptoms during the evaluation period; infections were visually assayed at 30 days postinoculation, and confirmed by PCR with universal begomovirus primers. ${ }^{(3)}$ Noninoculated. 

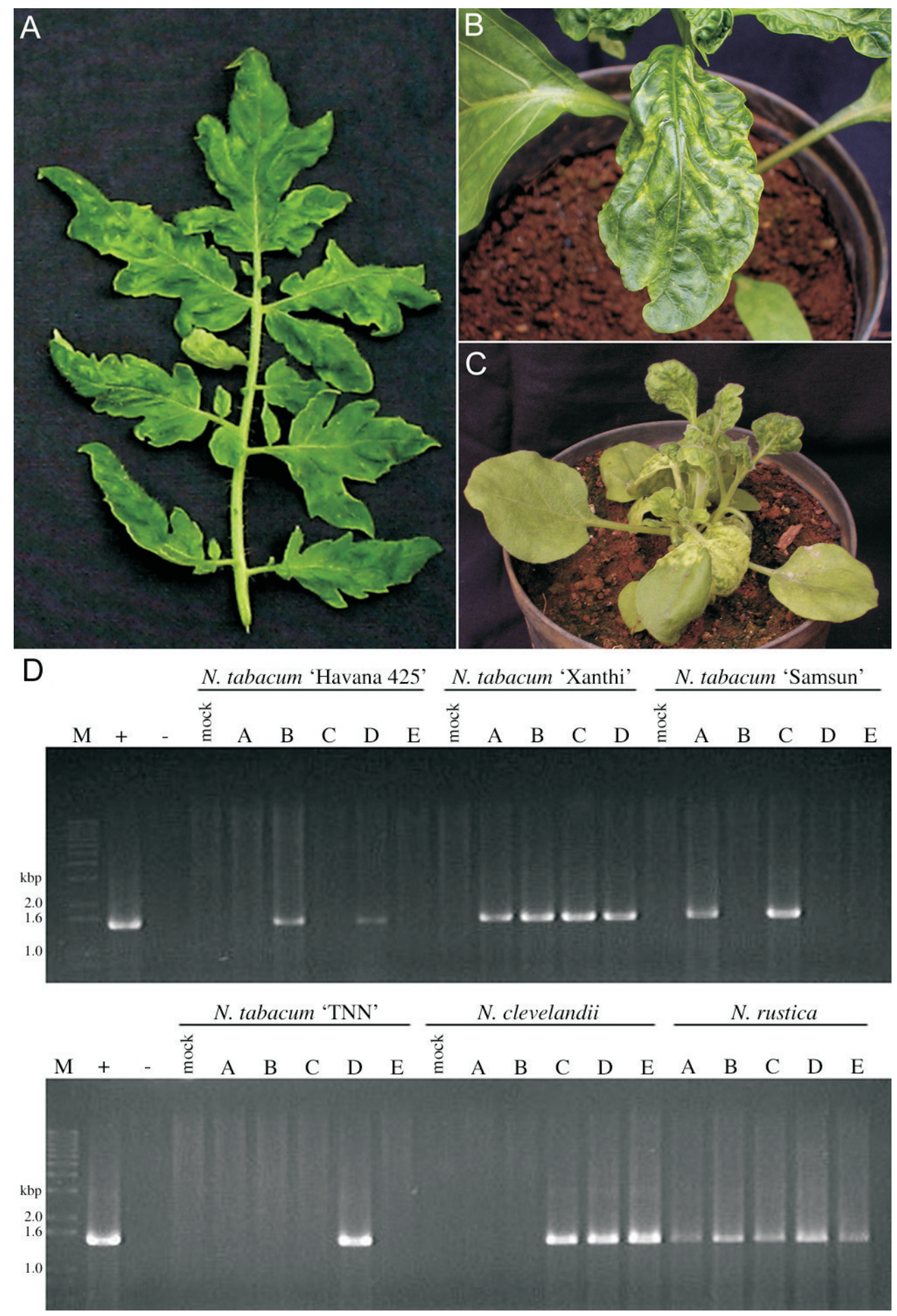

Figure 1. Symptoms induced in tomato (A), sweet pepper (B) and Nicotiana benthamiana (C), after biolistic inoculation with Tomato yellow spot virus-[Bi2] (ToYSV-[Bi2]). D: PCR-amplification of a DNA-A-specific fragment from plants sap-inoculated with ToYSV-[Bi2]. M, DNA ladder; + , amplification from a $N$. benthamiana plant infected with ToYSV-[Bi2]; -, amplification from a mock-inoculated tomato plant. 
When plants were biolistically inoculated, a systemic infection was established in $N$. benthamiana, $N$. glutinosa, $N$. tabacum, sweet pepper, tomato and G. globosa. In contrast, plants of $D$. stramonium, $N$. clevelandi, $N$. rustica and $N$. silvestris were systemically infected only when sap-inoculated.

It is noteworthy that sweet pepper is a host for TGV[Bi2] and displays severe symptoms upon infection. Furthermore, the common weed $D$. stramonium was also infected by TGV-[Bi2] and could serve as a virus reservoir in the field.

In summary, the host range of TGV-[Bi2] is similar to that of ToRMV and ToCMoV in which it is restricted to the Solanaceae. ToCMoV also infects important crop species such as sweet pepper and tobacco, as well as D. stramonium (Ambrozevicius et al., 2002; Ribeiro et al., 2007). ToRMV infects potato, tobacco, D. stramonium and Nicandra physaloides, but does not infect sweet pepper (Fernandes et al., 2006).

The complete genome of TGV-[Bi2] was amplified using the DNA polymerase of phage $\varphi 29$ (Figure 2 A). Restriction analysis indicated that $S a c$ I and $X b a$ I cleaved both DNA components at a single site (Figure $2 \mathrm{~B}$ ), and therefore these enzymes were used for cloning. Recombinant plasmids containing inserts of approximately 2,600 nt, corresponding to full-length DNA-A and DNA-B, were obtained (Figure 2 C).
The complete nucleotide sequences of the DNA-A and DNA-B of TGV-[Bi2] are 2,674 and 2,626 nt long (GenBank accession numbers DQ336350 and DQ336351, respectively). Both components have all the typical features of bipartite, New World begomoviruses, including six open reading frames (four in DNA-A, two in DNA-B) and a common region with approximately $200 \mathrm{nt}$, containing the origin of replication and the conserved elements (iterons) required for origin recognition by the Rep protein.

Sequence comparisons with other begomoviruses indicated a maximum sequence identity for the complete nucleotide sequence of the DNA-A of $87 \%$ with SiMoV, $83 \%$ with SiYMV and $81 \%$ with SimMV (Table 3 ). The DNA-B has a maximum nucleotide sequence identity of $79 \%$ with $\mathrm{SiMoV}$ and $66 \%$ with SimMV. Amino acid sequence identities calculated for each viral protein indicated a maximum identity with $\mathrm{SiMoV}$ for all proteins, ranging from $86 \%$ for the Rep and Ren proteins to $96 \%$ for the capsid protein (Table 3). According to current ICTV criteria for the demarcation of begomovirus species (Stanley et al., 2005), these results indicate that TGV-[Bi2] constitutes a novel begomovirus species, hereby named Tomato yellow spot virus (ToYSV[Bi2]), since it displayed less than $89 \%$ nucleotide sequence identity for the DNA-A with other viruses.

Phylogenetic trees based on the complete nucleotide sequences of the DNA-A and DNA-B are presented in Figure 3. Both trees clearly separate begomoviruses on
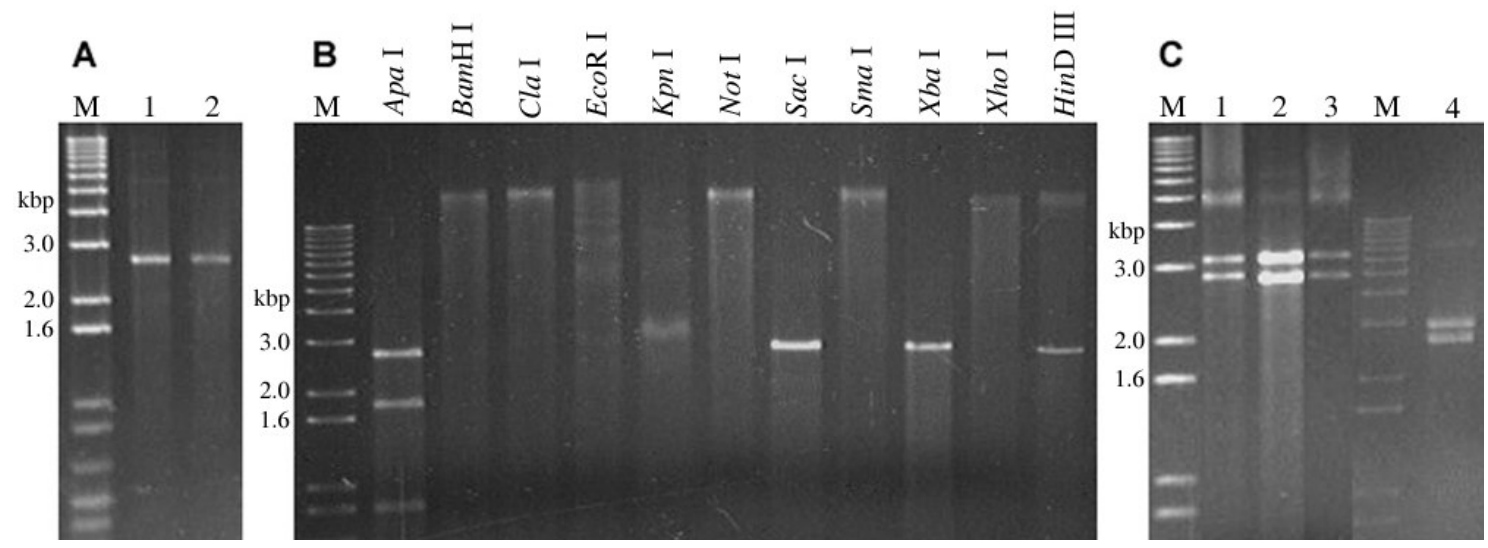

Figure 2. A: amplification of the full-length DNA components of Tomato yellow spot virus-[Bi2] (ToYSV-[Bi2]), using the DNA polymerase of phage $\varphi 29$; M: DNA ladder; 1-2: amplification of full-length DNA components $(\sim 2.6 \mathrm{kbp})$ from an infected Nicotiana glutinosa plant. B: restriction analysis of amplified full-length DNA components. Bands migrating slower than $2.6 \mathrm{kbp}$ correspond to noncleaved DNA components. Bands migrating at approximately $2.6 \mathrm{kbp}$ correspond to DNA components cleaved at a single site. Bands migrating faster than $2.6 \mathrm{kbp}$ correspond to fragments of DNA components cleaved at least twice. The enzymes Sac I and Xba I linearized both DNA components. M: DNA ladder. C: recombinant plasmids containing inserts corresponding to the complete DNA-A and DNA-B. M: DNA ladder; 1-3, recombinant plasmids cleaved with $S a c$ I; 4, recombinant plasmid cleaved with $\mathrm{Xba}$ I. 
Table 3. Nucleotide and amino acid sequence identities between Tomato yellow spot virus-[Bi2] (ToYSV-[Bi2]) and some closely related begomoviruses ${ }^{(1)}$.

\begin{tabular}{|c|c|c|c|c|c|c|c|c|}
\hline \multirow[t]{2}{*}{ Viral species } & \multicolumn{8}{|c|}{ Percent identities with ToYSV-[Bi2 $]^{(2)}$} \\
\hline & DNA-A & DNA-B & $\mathrm{CP}$ & Rep & Trap & Ren & MP & NSP \\
\hline $\begin{array}{l}\text { Sida mottle virus } \\
\text { (SiMoV-[A1B3]) }\end{array}$ & 87 & 79 & 96 & 86 & 88 & 86 & 94 & 87 \\
\hline Sida yellow mosaic virus (SiYMV) & 83 & n.a. ${ }^{(3)}$ & 89 & 75 & 73 & 72 & n.a. & n.a. \\
\hline $\begin{array}{l}\text { Sida micrantha mosaic virus } \\
\text { (SimMV-[A2B2]) }\end{array}$ & 81 & 66 & 95 & 84 & 76 & 76 & 80 & 78 \\
\hline $\begin{array}{l}\text { Tomato severe rugose virus } \\
\text { (ToSRV-[Ub2) }\end{array}$ & 78 & n.a. & 90 & 79 & 71 & 78 & n.a. & n.a. \\
\hline Tomato rugose mosaic virus (ToRMV) & 77 & 63 & 90 & 80 & 71 & 78 & 78 & 73 \\
\hline Tomato golden mosaic virus (TGMV) & 76 & 62 & 89 & 80 & 69 & 80 & 84 & 72 \\
\hline $\begin{array}{l}\text { Tomato chlorotic mottle virus } \\
\text { ToCMoV-[BA-Se1]) }\end{array}$ & 75 & 60 & 90 & 74 & 68 & 77 & 77 & 70 \\
\hline Bean golden mosaic virus (BGMV) & 75 & 62 & 92 & 77 & 74 & 77 & 79 & 73 \\
\hline
\end{tabular}

${ }^{(1)} \mathrm{CP}$, coat protein; Rep, replication-associated protein; Trap, trans-activating protein; Ren, replication enhancer protein; MP, movement protein; NSP, nuclear shuttle protein. ${ }^{(2)}$ Nucleotide sequence identities for DNA-A and DNA-B, deduced amino acid sequence identities for the viral proteins. ${ }^{(3)}$ Sequence not available.
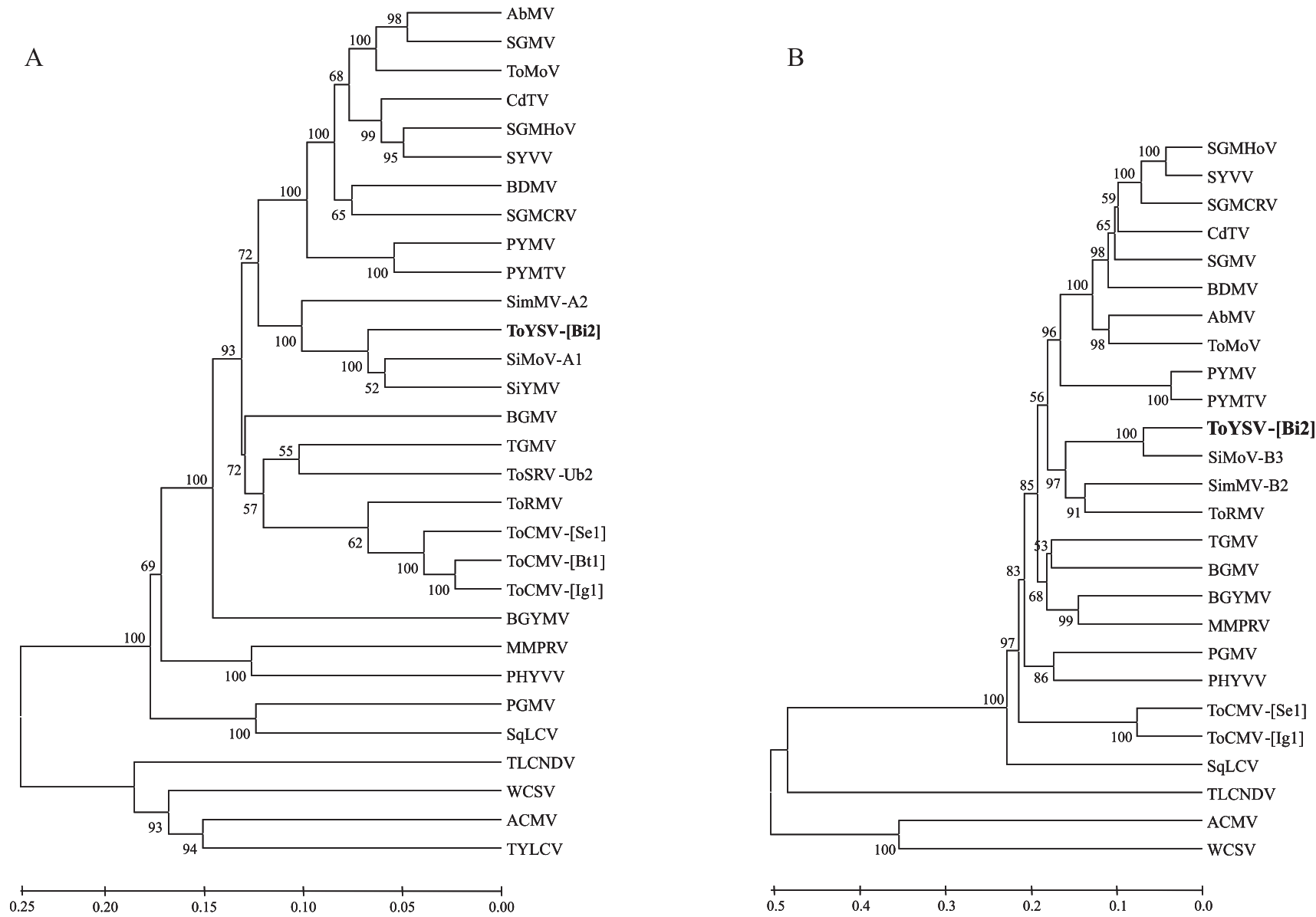

Figure 3. Phylogenetic tree based on a multiple sequence alignment of the complete DNA-A (A) and DNA-B (B) of selected New World begomoviruses, using the UPGMA method. Branches were bootstrapped with 1,000 replications. Acronyms and accession numbers are in Table 1 . The scale indicates the number of substitutions per site. 
the basis of geographical location, with Brazilian viruses clustered together. In the tree based on DNA-A, ToYSV[Bi2] is located in a monophyletic branch with $100 \%$ bootstrap value including the three Sida begomoviruses from Brazil, SimMV, SiMoV and SiYMV. In the tree based on DNA-B, ToYSV-[Bi2] is located in a monophyletic branch with $97 \%$ bootstrap value including SimMV, SiMoV and ToRMV (there is no DNA-B sequence available for SiYMV). Together, these results reinforce those of sequence comparisons, indicating a close relationship between ToYSV and the Brazilian Sida-infecting begomoviruses.

The hypothesis to explain the sudden and rapid emergence of tomato-infecting begomoviruses in Brazil assumes that indigenous viruses were transferred from wild hosts to tomatoes after the introduction and dissemination of the B biotype of B. tabaci. The new vector allowed these indigenous viruses to reach a new host, where mechanisms of recombination and pseudorecombination (reassortment of genomic components) generated novel species with greater fitness to the new host (Inoue-Nagata et al., 2006; Ribeiro et al., 2007). On the basis of this close relationship with Sidainfecting viruses, its severe phenotype in tomatoes and its low relative incidence in the field, it is tempting to speculate that ToYSV could be a "missing link" between an indigenous Sida-infecting virus, such as SiMoV (which has never been detected in tomatoes), and the more widespread (and therefore better adapted) tomato-infecting begomoviruses, such as ToRMV and ToCMoV. Alternatively, it could have arisen by recombination involving one of the Sida-infecting viruses. Recombination has been proposed to play a major role in the emergence and evolution of tomato-infecting begomoviruses in Brazil (Ribeiro et al., 2007). Initial attempts to verify the role of recombination in the origin of ToYSV led to inconclusive results. The identification and molecular characterization of additional begomovirus species may be necessary before such analysis yields more definitive results.

\section{Conclusions}

1. The host range of ToYSV includes several solanaceous plants, with economically important crop plants as sweet pepper, and common weeds such as Datura stramonium.

2. Unlike other tomato-infecting begomoviruses from Brazil, ToYSV is readily sap-transmitted to some hosts such as Nicotiana benthamiana, but not to tomato.
3. Based on sequence comparisons and phylogenetic analysis, and in accordance with current ICTV criteria, ToYSV is a distinct begomovirus species.

4. ToYSV is phylogenetically closer to viruses infecting the weed Sida sp. than to viruses infecting tomato.

\section{Acknowledgements}

To CNPq, for scholarships and for finnancial support; to Fapemig, for finnancial support.

\section{References}

AMBROZEVICIUS, L.P.; CALEGARIO, R.F.; FONTES, E.P.B.; CARVALHO, M.G.; ZERBINI, F.M. Genetic diversity of begomoviruses infecting tomato and associated weeds in Southeastern Brazil. Fitopatologia Brasileira, v.27, p.372-377, 2002.

ARAGÃO, F.J.L.; BARROS, L.M.G.; BRASILEIRO, A.C.M.; RIBEIRO, S.G.; SMITH, F.D.; SANFORD, J.C.; FARIA, J.C.; RECH, E.L. Inheritance of foreign genes in transgenic bean (Phaseolus vulgaris $\mathrm{L}$.) co-transformed via particle bombardment. Theoretical and Applied Genetics, v.93, p.142-150, 1996.

ARIYO, O.A.; ATIRI, G.I.; DIXON, A.G.O.; WINTER, S. The use of biolistic inoculation of cassava mosaic begomoviruses in screening cassava for resistance to cassava mosaic disease. Journal of Virological Methods, v.137, p.43-50, 2006.

BRIDDON, R.W. Cotton leaf curl disease, a multicomponent begomovirus complex. Molecular Plant Pathology, v.4, p.427-434, 2003.

DELLAPORTA, S.L.; WOOD, J.; HICKS, J.B. A plant DNA minipreparation: Version II. Plant Molecular Biology Reporter, v.1, p.19-21, 1983.

FERNANDES, J.J.; CARVALHO, M.G.; ANDRADE, E.C.; BROMMONSCHENKEL, S.H.; FONTES, E.P.B.; ZERBINI, F.M. Biological and molecular properties of Tomato rugose mosaic virus (ToRMV), a new tomato-infecting begomovirus from Brazil. Plant Pathology, v.55, p.513-522, 2006.

GILBERTSON, R.L.; FARIA, J.C.; HANSON, S.F.; MORALES, F.J.; AHLQUIST, P.G.; MAXWELL, D.P.; RUSSELL, D.R. Cloning of the complete DNA genomes of four bean-infecting geminiviruses and determining their infectivity by electric discharge particle acceleration. Phytopathology, v.81, p.980-985, 1991.

INOUE-NAGATA, A.K.; MARTIN, D.P.; BOITEUX, L.S.; GIORDANO, L.D.; BEZERRA, I.C.; DE AVILA, A.C. New species emergence via recombination among isolates of the Brazilian tomato infecting Begomovirus complex. Pesquisa Agropecuária Brasileira, v.41, p.1329-1332, 2006.

JOVEL, J.; RESKI, G.; ROTHENSTEIN, D.; RINGEL, M.; FRISCHMUTH, T.; JESKE, H. Sida micrantha mosaic is associated with a complex infection of begomoviruses different from Abutilon mosaic virus. Archives of Virology, v.149, p.829-841, 2004.

KUMAR, S.; TAMURA, K.; NEI, M. MEGA3: Integrated software for molecular evolutionary genetic analysis and sequence alignment. Briefings in Bioinformatics, v.5, p.150-163, 2004. 
LEGG, J.P.; THRESH, J.M. Cassava mosaic virus disease in East Africa: a dynamic disease in a changing environment. Virus Research, v.71, p.135-149, 2000.

MORALES, F.J.; ANDERSON, P.K. The emergence and dissemination of whitefly-transmitted geminiviruses in Latin America. Archives of Virology, v.146, p.415-441, 2001.

POLSTON, J.E.; ANDERSON, P.K. The emergence of whiteflytransmitted geminiviruses in tomato in the Western hemisphere. Plant Disease, v.81, p.1358-1369, 1997.

RAJESHWARI, R.; REDDY, R.V.C.; MARUTHI, M.N.; COLVIN, J.; SEAL, S.E.; MUNIYAPPA, V. Host range, vector relationships and sequence comparison of a begomovirus infecting hibiscus in India. Annals of Applied Biology, v.147, p.15-25, 2005.

RIBEIRO, S.G.; AMBROZEVICIUS, L.P.; ÁVILA, A.C.; BEZERRA, I.C.; CALEGARIO, R.F.; FERNANDES, J.J.; LIMA, M.F.; MELLO, R.N.; ROCHA, H.; ZERBINI, F.M. Distribution and genetic diversity of tomato-infecting begomoviruses in Brazil. Archives of Virology, v.148, p.281-295, 2003.

RIBEIRO, S.G.; MARTIN, D.P.; LACORTE, C.; SIMÕES, I.C.; ORLANDINI, D.R.S.; INOUE-NAGATA, A.K. Molecular and biological characterization of Tomato chlorotic mottle virus suggests that recombination underlies the evolution and diversity of Brazilian tomato begomoviruses. Phytopathology, v.97, p.702-711, 2007.

ROJAS, M.R.; GILBERTSON, R.L.; RUSSELL, D.R.; MAXWELL, D.P. Use of degenerate primers in the polymerase chain reaction to detect whitefly-transmitted geminiviruses. Plant Disease, v.77, p.340-347, 1993.
ROJAS, M.R.; HAGEN, C.; LUCAS, W.J.; GILBERTSON, R.L. Exploiting chinks in the plant's armor: evolution and emergence of geminiviruses. Annual Review of Phytopathology, v.43, p.361-394, 2005.

ROTHENSTEIN, D.; BRIDDON, R.W.; HAIBLE, D.; STANLEY, J.; FRISCHMUTH, T.; JESKE, H. Biolistic infection of cassava using cloned components of Indian cassava mosaic virus. Archives of Virology, v.150, p.1669-1675, 2005.

SAMBROOK, J.; RUSSEL, D. Molecular cloning: a laboratory manual. Cold Spring Harbor, NY: Cold Spring Harbor Laboratory Press, 2001. 3.ed. 2344p.

STANLEY, J.; BISARO, D.M.; BRIDDON, R.W.; BROWN, J.K.; FAUQUET, C.M.; HARRISON, B.D.; RYBICKI, E.P.; STENGER, D.C. Family Geminiviridae. In: FAUQUET, C.M.; MAYO, M.A.; MANILOFF, J.; DESSELBERGER, U.; BALL, L.A. (Ed.). Virus taxonomy: eighth report of the International Committee on Taxonomy of Viruses. San Diego: Elsevier Academic Press, 2005. p.301-326.

THOMPSON, J.D.; HIGGINS, D.G.; GIBSON, T.J. CLUSTAL W: improving the sensitivity of progressive multiple sequence alignment through sequence weighting, position-specific gap penalties and weight matrix choice. Nucleic Acids Research, v.22, p.4673-4680, 1994.

URBINO, C.; POLSTON, J.E.; PATTE, C.P.; CARUANA, M.L. Characterization and genetic diversity of Potato yellow mosaic virus from the Caribbean. Archives of Virology, v.149, p.417-424, 2004. 